\title{
University Canteen Business Process Improvement to Increase Sustainability
}

\author{
Christina Wirawan \\ School of Business Management, Bandung Institute of Technology
}

\begin{abstract}
The awareness about limited and environmentally burdened tangible products prompted service science development. Service sector becoming an important sector because it gives significant value-added. Because of the strategic role, there's a need for developing strategies that aim to increase service's performance and sustainability. By improving the service blueprint and use value-orchestration strategy can help service business to raise their performance and sustain. In this article, a university canteen in a private university, as one of service business, studied. The canteen runs by a business unit. The canteen needs to raise its performance to survive and sustain in a competitive environment. Nowadays only about $5 \%$ of all students, lecturers and employees in the university buy food in the canteen. That means there are still many potential opportunities to improve its performance. This article enhances the canteen's service blueprint that reduces time and cost. This improvement enabled by the value orchestration strategy that increasing customer's roles in the process. This article contributes to the body of knowledge about the implementation of blueprint analysis and value orchestration strategy to help a service sector to raise performance and sustain.
\end{abstract}

Keywords: service sector, service blueprint, value orchestration

\section{Introduction}

The sharp increasing peoples' consumption of tangible products predicted would cause tremendous productivity raised as well as caused significant environmental burden (Mont, 2002). Service sector development has been promoted with science and technology development, especially at the information technology area. In the other side, the speedy growth of information, science, technology and product design have increased customers' expectation and needs. This condition is also encouraging service sectors development. Service sectors development raise the value-added generated from the innovation of new business models created that further to GDP raise. Considering the importance of service sectors development, they need to be sustained.

To be sustained, service sectors need to implement an appropriate strategy. Service science concept would be necessary to build the strategy. Service science attempt to explain and improve interactions of entities, to co-create value and develop theories and methods for solving unique problems at the service sector (Spohrer and Maglio, 2008). Using service science, service sectors can broadly develop to create value more efficiently and effectively that maintain and raise performance and sustainability.

Service science studies value co-creation where entities (e.g. customer, provider, etc.) can interact to co-create value (Maglio, Vargo, Caswell and Jim Spohrer, 2009). In co-creating value, service also sometimes need a platform that can bring together customers and providers to do activities to create value together (Kijima and Arai, 2016).

In this paper, a case study about a canteen located in a private university in Bandung studied. Service science implemented to develop strategies for the canteen to raise its performance inter of profitability to sustain. To be profitable, the canteen must be attractive enough for the customer to buy food there. Canteen must deliver excellent service and hire good tenants To attract the customer. And to obtain good tenants, canteen must have the ability to give good attractive profit for them. Based on this condition and competition from the food sellers around the university, the canteen must have a strategy to be profitable and sustainable. 
The current condition, although located in the strategic location in one of the buildings in the university, the percentage of students, lecturers, and employees that come and buy food in this canteen relatively low, only about $5 \%$ per day. This condition implies that students, lecturers, and employees do not like to purchase food at the canteen. Moreover, there is still significant potential market share as an opportunity to raise the business.

The low rate of customers is one of the problems. Another problem faced in this canteen is that the tenants must open from 07.00 am to $09.00 \mathrm{pm}$ to serve students, lecturers and employees in their activities. But actually, after $03.00 \mathrm{pm}$ there are relatively few people who come to buy food, and the customers decrease drastically after $06.00 \mathrm{pm}$. But the tenants may not close after that because the canteen commits to serving food until the teaching-learning process ended. This paper will try to use service science to win the market share of the canteen by creating value co-creation platform. Using the value orchestration strategy, we develop the new business model and utilize the relatively idle capacity after 03.00 p.m. to increase profit and sustainability.

Based on the problems, then the research questions build are:

1. Why don't people in the university like to buy food at the canteen?

2. How can the canteen increase food buyer?

3. How can the canteen increase income from utilizing idle capacity?

The research objective is to increase canteen's performance and sustainability through service blueprint improvement and a new business model implementation. These efforts logically would increase numbers of buyers, which reasonably increase canteen's income.

The rest of this paper will describe the literature review, the existing canteen university service system and the problem faced. Next, we explain the methodology used to solve the problem. After that, we describe the result and discussion of the problem found and the proposed system to improve the system to be more profitable and sustainable, followed by the proposed system. The article closed with the conclusion and future research.

\section{Literature Review}

As mentioned above, this section will describe a literature review that becomes based on the proposed system improvement and also the description of the existing canteen university service system.

In recent years, the service sector develops fast in quantity and variation. Service sector creates more value-added that contribute to GDP. Because of its significant role and contribution, service becomes a critical sector to develop and become a consideration to run the business in this sector more efficiently and effectively to get optimal gain. As the service sector grows, service science developed. "Service science is short for Service Science, Management, Engineering, and Design, also known as SSMED" (Maglio, Vargo, Caswell and Jim Spohrer, 2009). According to IBM "Service Science, Management and Engineering is new multi-disciplinary research and academic effort that integrates aspects of established fields such as computer science, operations research, engineering, management sciences, business strategy, social and cognitive sciences, legal science" (Spohrer and Maglio, 2008).

According to Spohrer and Maglio (2010), research about service already conduct by scholars over the last two hundred years in definitions, optimal exchange, service growth, result of service growth, model of service system, service marketing, service quality, optimal learning, optimal investment, service operations, B2B service, service design, service innovation, lean technique (Spohrer and Maglio, 2010). Service science develops theories and methods for solving unique problems in the service sector by explaining and improve the interactions of entities to work together and gain mutual benefits (Spohrer and Maglio, 2008). 
In past decades, there are attempts to transform industries from goods orientation (Goods Dominant Logic/ GDL) to service orientation (Service-Dominant Logic/ SDL) (Maglio et al., 2009). GDL focused on tangible resources transaction (Vargo and Lusch, 2004), transaction value and production process are embedded value to the product (Mele, Colurcio and Russo-Spena, 2014). The implication of GDL is that producer has a responsibility to create value in the product before ownership transfer after the transaction, the responsibility of the provider ended (Ng et al., 2012). In GDL, there are differences between producer and client and their value system (Vargo and Lusch, 2008). The paradigm shifts from GDL to SDL (Vargo and Lusch, 2004; Spohrer and Maglio, 2008) is an effort to innovate and co-create value. Product and service integration that makes a closer relationship between providers and customers (Korhonen, 2014). Customer participation can happen in the innovation process and value co-creation (Korhonen, 2014) that can provide individualized and interactive design to bring the solution to sophisticated customers' problems (Evanschitzky, Wangenheim and Woisetschlager, 2011).

SDL viewed all transaction base on service, goods included in transaction tools to preparing and human resource application (Lusch and Vargo, 2006). It means that goods are equipment for service delivery (Vargo and Lusch, 2008; Wennerholm, 2012). SDL state that with customers, value co-created all the time (Vargo and Lusch, 2008). Value co-created with the simultaneous effort of a company, personal, customer, stakeholder, government and other entity that relate to the transaction, but the decision lies on the receiver(Vargo and Lusch, 2008). Innovation perceives as a process where provider and user collaborate to find the solution to integrate resources and help develop value creation (Mele, Colurc io and Russo-Spena, 2014).

To enable and support value co-creation, customers and providers need media to interact with each other and co-create new value (Kijima and Arai, 2016). Value orchestration platform facilitates value co-creation that invite customers and providers to co-create value (Kijima and Arai, 2016). According to Kijima and Arai (2016), there is four-phase of the co-creation process, co-definition, co-experience, co-elevation and co-development that involving customers and providers. Regarding the co-creation, there are three strategies for value co-creation management: involvement, curation, and empowerment (Kijima and Arai, 2016).

One of the factors of service that believed to have a direct effect on buying and customer loyalty is service quality. Qualitative service transfer different from product transfer because there are no physical goods given to the customer, service production is nonmaterial asset transfer from provider to the customer (Quinn and Cameron, 1993; Grönroos and Gummerus, 2014). The most well-known service quality measurement is SERVQUAL, constructed by Parasuraman. SERVQUAL measuring service quality with gaps between expectation and perceived performance that broadly implements in many business contexts (Jiang et al., 2012). Although there are many debates and critics about Parasuraman's SERVQUAL in many aspects, this method was very popular and broadly used by researchers and industries to measure and improve service quality. Parasuraman, Zeithaml and Berry (1985) concluded, there are ten dimensions as indicators to determine service quality that squeezed into five dimensions (1) tangibles (2) reliability (3) responsiveness (4) assurance and (5) empathy. Each item is measured based on responses that measure: (1) the general expectations of customers concerning a service; and (2) the perceptions of customers regarding the levels of service provided by the company within that service category (Ladhari, 2009).

In the university, canteen is an essential supporting facility to provide food that supports teachinglearning and other activities in the university. Providing a good canteen can help peoples in the campus, as customers, to find food easily, comfort, quickly, with affordable price, as well as giving a nice place to rest and refresh. Therefore, university canteen must design to meet customer needs. In fact, in a university, the canteen faces a tough competitive situation with many food sellers around. There are very much food sellers around the university with very various type, quality and price of food offered. The competition affected the canteen attractiveness for tenants. If canteen doesn't look attractive enough to tenants, then canteen will get difficulties to find good tenants and 
in turn, failed to attract customer to come. To solve the problems, we use a methodology as described next.

\section{Methodology}

This article is a problem-solving article which is to study the university canteen and try to solve the problem exist to help the canteen to raise its performance and sustain. To solve the problem, we conduct five steps, (1) observe the canteen, (2) doing the qualitative survey, (3) identified the main issue, (4) improve service blueprint, (5) built value orchestration strategy.

The first step is observation. We conduct it by observed the canteen for two months with random time. While the second step is a qualitative survey, conducted by interviewing tenants, students, teachers and employees who were experienced to buy food at the canteen to find the ir expectations and needs. At the third step, we tried to breakdown and deployed customers' expectations and needs and compared them with the canteen existing condition, to find where the improvement must be taking place. Next, we studied the existing service blueprint and found the failed points to be improved. At the last step, we built suggestion using value orchestration strategy to raise the canteen's performance and sustainability.

\section{Result and Discussion}

As a result of observation and survey conducted, we found that the canteen opens from Monday to Friday, at 07.00 a.m. until $09.00 \mathrm{p}$. m. The university canteen located on the first floor of a lecture hall in the university. This canteen managed by a particular business unit under the university foundation. The business unit provides the place, stalls, eating area with tables and chairs, cashier and equipment. Cleaning service officers or cleaners have the responsibility to clean all area of the canteen and wash the dirty dishes. And deliverer that have a responsibility to deliver food from and to table and stalls. Stalls run by tenants that shared profit with the business unit. Tenants provide cooking equipment, stall equipment, and eating equipment by themselves. The canteen opens at 07.00 a.m. to 09.00 p.m. from Monday to Friday to support campus activities. Tenants must open their stalls at this time. Tenants that not meet that regulation will be charged as a penalty.

Usually, canteen only has very high demand at lunchtime from about 11.00 a.m. to 01.00 p.m., medium demand from 08.00 a.m. to 11.00 a.m. and 01.00 p.m. to 03.00 p.m. The canteen experienced low demand start at 03.00 p.m. to 06.00 p.m. and after 06.00 p.m. deficient demand. The average frequency of customer buys food at canteen mostly only once to twice a week and less than once a week.

From interviewing students, lecturers and employees as customers, several factors that university canteen must consider: (1) they can serve customers easily, (2) serve customer quickly because sometimes customers have a tight schedule, (3) comfortable place because customers need to rest and refresh after or before doing activities, but also with (4) cheap price to win competition with other food sellers around the university. Canteen must have a simple, quick and safe system to serve customer quickly and easily. Moreover, canteen needs to have good design, clean and have an excellent atmosphere to comfort the customer. Beside, canteen must use resource efficiently, especially supporting resources, and make do a new business model to give a lower price. According to Parasuraman (1985), service quality can be measured by five dimensions, tangibles, responsiveness, empathy, assurance, reliability.

As mentioned before, from the survey, good canteen must serve customers easily, quickly, give comfort place and have a low price. Base on these factors, the cause of only a few customers buy food at canteen will be analyzed and traced. Easy, quick and comfort factors can be related to Parasuraman's dimension of quality as shown in table 1, while cheap factor related to co-creation, efficiency, and utilization. 
Table 1. Relation Between Indicators and SERVQUAL Dimensions

\begin{tabular}{|c|c|c|c|}
\hline & Easy & Quick & Comfort \\
\hline Tangibles & & - Facilities adequacy & $\begin{array}{l}\text { - Facilities comforts } \\
\text { - Atmosphere comforts } \\
\text { - Cleanliness }\end{array}$ \\
\hline Responsiveness & - Process ease & $\begin{array}{l}\text { - Receiver and chef } \\
\text { speed } \\
\text { - Cashier speed } \\
\text { - Deliverer speed } \\
\text { - Cleaner speed } \\
\text { - Procedure }\end{array}$ & \\
\hline Empathy & - Simple procedure & & - Custom food \\
\hline Assurance & & & - Food cleanliness \\
\hline Reliability & $\begin{array}{l}\text { - System } \\
\text { consistency }\end{array}$ & - System consistency & $\begin{array}{l}\text { - Taste consistency } \\
\text { - Price consistency }\end{array}$ \\
\hline
\end{tabular}

Each factors discussion:

1. Comfort

The existing condition of physical evidence in the canteen is in excellent condition with good quality air, good light and proper temperature, a strategic location at the first floor of teaching-learning and library building, and comfortable furniture. In the centre of canteen also there is a stage that can be used for performance or another event. The canteen also has a clean floor, table, chair, stalls and also equipped with a clean and good condition of a toilet. This condition is already satisfied customers as a result of the survey. Custom food in the limited state can be ordered to tenants. Tenants regulate to serve good and clean food. Taste consistency relatively good because most tenants' chef is the owner. Price can be inconsistent because each tenant makes each receipt for each customer.

2. Quick

Facilities adequacy is not the root cause, sometimes because of the long-time customer need in the canteen, make table and chair inadequate. The speed of service from the receiver, chef, and cashier quick enough, de liverer and cleaner work fast but sometimes in rush hour they're overloaded, and customers need to wait. The process of order food is long that make the long time required.

3. Easy

The process of ordering food relatively long and complicated because there are several processes that customers must do, and in more than one place, without explanation or guide.

4. Low price

The price in the canteen relatively expensive compared with the food seller around the university. This high price is because tenants must share profit with the business unit. The business unit must count cleaner and deliverer cost while they determine the share. Another cause of high price is because tenant must spend time and cost to operate stalls until 09.00 p.m., whereas demand is low.

From the analysis, it can be concluded that there are three problems: (1) long and complicated procedure, (2) efficiency, (3) idle capacity in some particular time.

Existing procedure in the canteen is as shown in service blueprint in figure 1. The customer enters the canteen, choose and go to the stall, choose food from the menu, and order the food at the stall. Stall's front staff receive the order, making a receipt and give it to the customer. The customer brings the receipt to the cashier and pays the order. The cashier inputs payment data, print the payment receipt and give it to the customer. The customer comes back to the stall to provide the receipt to the front staff and receive table number. The front staff puts order to the chef that will 
prepare the food. After the food is ready, the front staff informs deliverer to bring and serve it to the customer. Deliverer picks up food from the stall and gives it to the customer at their table. A customer eats and after it, a cleaner clean up the table and take dirty dishes and wash it. With this process, there's a long process that customers must do before they can sit.

Moreover, cleaner and deliverer sometimes too busy so that the customer must wait for the table to be cleaned or wait for the food delivered to them. This lengthy process takes longer customer's time in the system. Next, it sometimes causes the table becomes full, and the customer can not find an empty table. In this system, several processes can be simplified to make it quicker, more straightforward and more convenience.

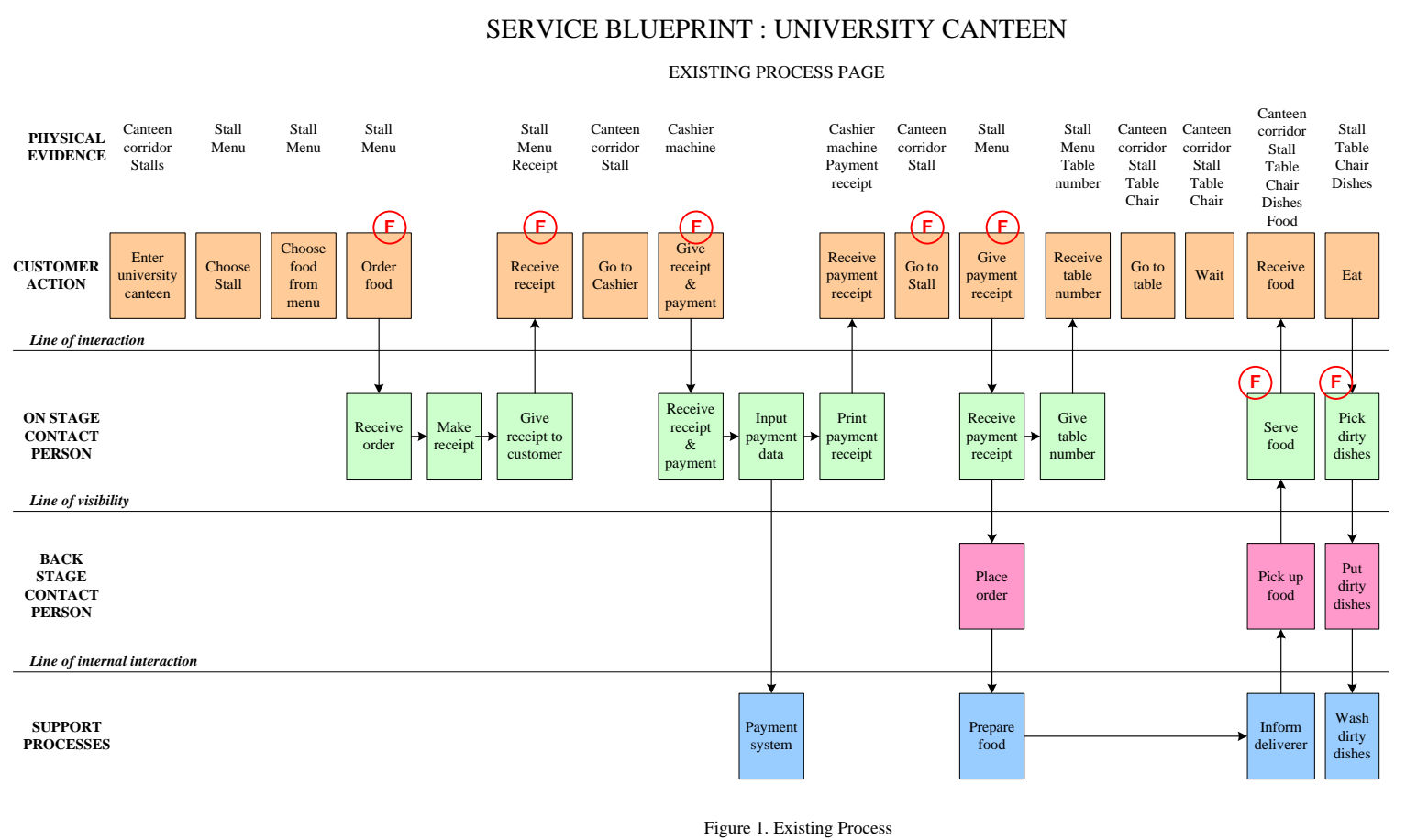

Figure 1. Existing Process

\section{Proposed Service}

In the previous part, three problems, (1) long and complicated procedure, (2) efficiency, (3) idle capacity in particular time founded. For the first problem, as shown in service blueprint in figure 1, in this system, several processes can be simplified to make it simpler and quicker. Improvement can be made when the customer must go to stall first to order the food, then go to the cashier and go back to the stall to give a receipt, before the food prepared and customers wait. The next potential improvement can be made when deliverer brings food to the table and cleaner take the dirty dish from the table.

To solve the first problem, the canteen can build an information system that connects cashier to every tenant and the business unit, as shown in figure 2. The food menu from all tenants pooled near canteen entry gate and at the cashier, so customers can choose the menu once they enter canteen. Customers don't need to go to stall first. They choose food directly go to the cashier to make payment. In the payment process, cashier input the detailed order of the customer that automatically linked by the system to the particular tenant. The system will inform tenants about the customer's order and customer number. Cashier prints the payment receipt that also contains the customer number, and gives it to the customer. With this system, the order process can be more straightforward and quicker. 


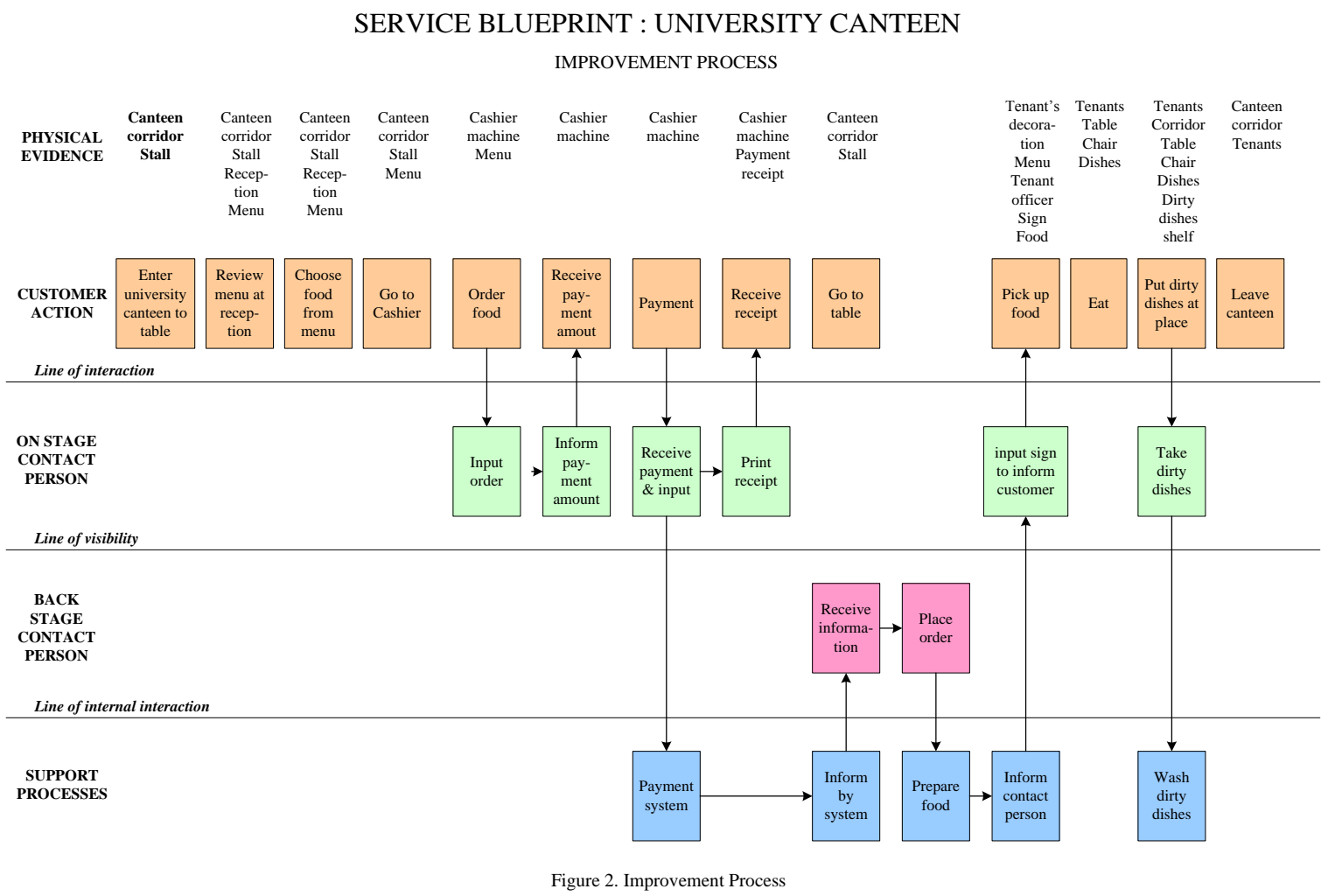

Figure 2. Improvement Process

To solve the second problem, the high price of food, canteen needs to raise efficiency and utilization of resources that can cut down the. Here, value co-creation concept can be adopted by increasing responsibility and activity of customer in the process, by moving to deliver food from stall to table activity and take the dirty dish from table to provided shelf to customer. With this design, de liverer can be eliminated, while the number of cleaners can be reduced. Reduction of the number of employee consequences that canteen can cut down cost and customers can get food with lower price and quicker process. This design also can help educate customers to be neat, responsible and always keep clean. To do this, in each stall provide a big enough sign display at the front of the stall that will be show number of order if the order ready. When the food is prepared already, the tenant can put it on display. The customer can see the display, and if his or her number shown in the display, he or she can take the food from the stall and take it to the table. Cleaner also can be reduced by assign customers to pick up dirty dishes to a shelf and throw the garbage to the garbage bin.

To solve the third problem, the suggestion is to develop value co-creation platform for delivery service to utilize idle time, especially after $6 \mathrm{p} . \mathrm{m}$. and can be started at $3.00 \mathrm{p} . \mathrm{m}$. The business unit can manage food delivery order for all stall, especially for internal campus and around campus. The service blueprint showed in figure 3. The customer can see the menu from a website, then order food through the website or call. The business unit receives the order and places the order to tenants to prepare food. If the food ready, the tenant will inform business unit that will make a receipt and pick up food to de liver to the customer. The food will be received by the customer and make a payment. Deliverer comes back to the canteen, give money to the cashier that will input it to the system. With this new business process, tenants can raise their profit and increase utilization of resources. Next, hopefully, the price can be lowered to attract more customer to buy food at the canteen, and attract more tenants to do business at the canteen. 


\section{SERVICE BLUEPRINT : UNIVERSITY CANTEEN}

NEW BUSINESS PROCESS

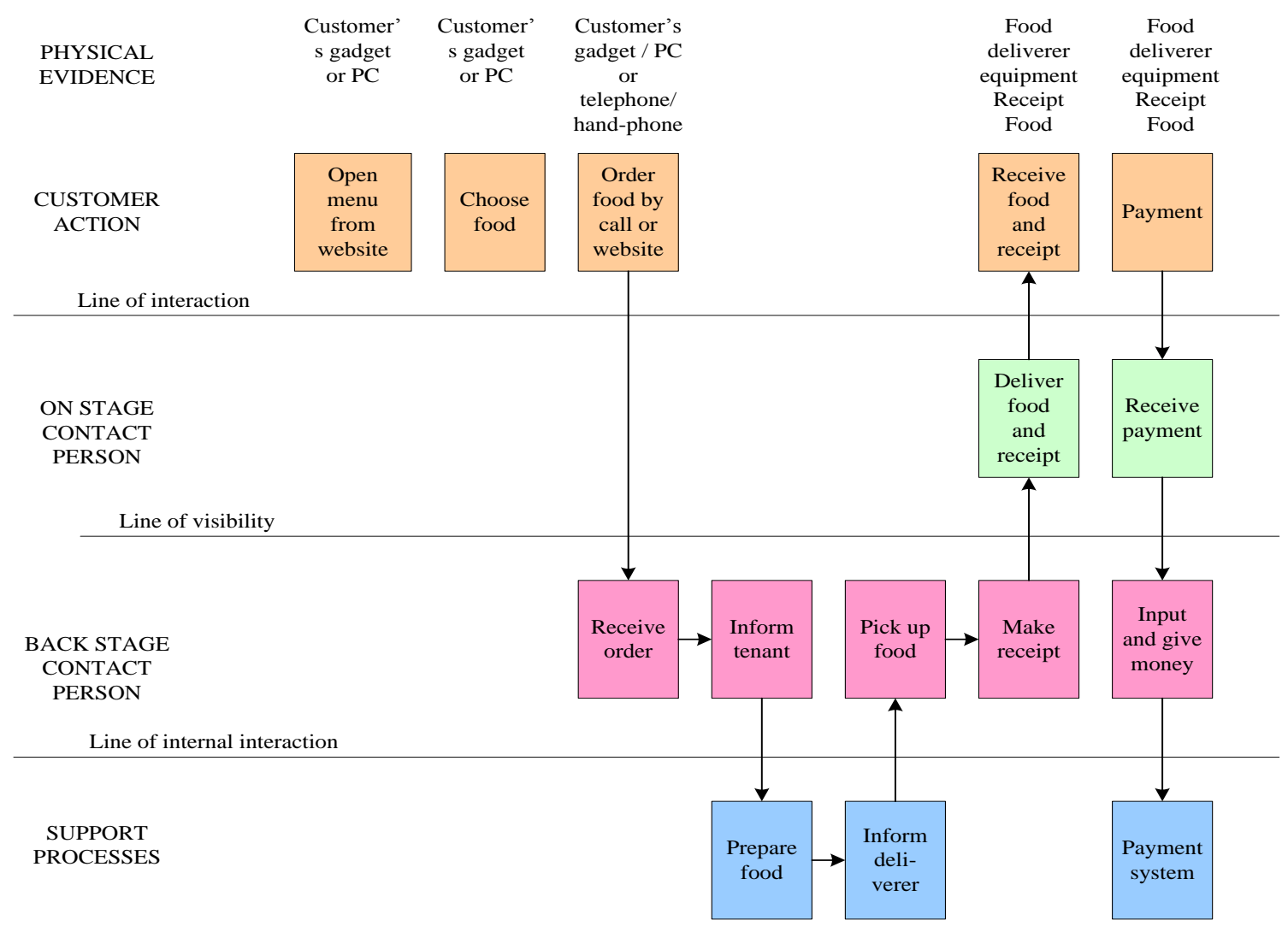

Figure 3. New Business Process

Figure 3. New Business Process

Value orchestration strategies are as shown in table 2. For involvement strategy, the website can also equip with a forum, comment part or chatting media. Customer can give suggestion or request to tenants or the business unit that can help them to develop the business, while tenant can interactively communicate with customers. With this strategy, customer and provider can together determine the optimal portion of food, acceptable price and delivery method that can satisfy both needs. For curation strategies, customer can suggest the provider, such as what variation of food menu and what taste of food they favour. Customer also can ask for a customized meal. The provider can design a healthy menu, and also can extend service with accepting the order of some goods from the mini-market around them that ask by customer. For involvement strategies, the business unit can suggest appropriate social media to use, give consultation or training for providers about e-commerce but also about variety and healthy cooking, and educate the customer about healthy food and healthy life. 
Table 2. Value Orchestration Strategy

\begin{tabular}{|c|c|c|c|}
\hline & \multicolumn{3}{|c|}{ Value Co-Creation Process } \\
\hline \multirow{4}{*}{ 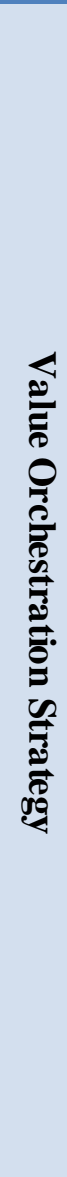 } & & $\begin{array}{l}\text { Co-expe rience } \\
\text { Co-definition }\end{array}$ & $\begin{array}{c}\text { Co-elevation } \\
\text { Co-development }\end{array}$ \\
\hline & Involve ment & $\begin{array}{l}\text { - Make forum for customer and } \\
\text { provider } \\
\text { o Determine the optimal portion } \\
\text { of food } \\
\text { o Determine optimal price } \\
\text { o Determine the optimal delivery } \\
\text { method }\end{array}$ & \\
\hline & Curation & & $\begin{array}{l}\text { - Make the suggestion forum: } \\
\circ \text { Develop variation of food } \\
\text { menu } \\
\circ \text { Develop the taste of food } \\
\text { - Customization of food } \\
\text { - Design a healthy menu } \\
\text { - Customer can ask the provider } \\
\text { also to buy some goods in } \\
\text { minimarket near the provider, } \\
\text { that will be delivered }\end{array}$ \\
\hline & Empowe rment & & $\begin{array}{l}\text { - Use appropriate social media } \\
\text { - Consultation or training for } \\
\text { providers about e-commerce } \\
\text { but also about variety and } \\
\text { healthy cooking } \\
\text { - Educate the customer about } \\
\text { healthy food and a healthy life }\end{array}$ \\
\hline
\end{tabular}

\section{Conclusion and Future Work}

From this research, it can be found that customers seek canteen to be easy, quick, give comfort place and have cheap price canteen. Most of the customers don't like to buy food at the canteen because the canteen doesn't have easily, quickly, and affordable price condition. To more attract customers, improvement of a procedure that increases ease and efficiency proposed. To use idle capacity and also raise tenants and business unit's income, value co-creation platform based foodservice delivery offered. With the improvement made, the canteen can operate more efficiently, quicker and easier. Next, the price can be lowered, so that it can attract more buyer and increase income. A good income can attract good quality tenants that in turn, would attract more customer. After proposing a food delivery service platform for the business unit, that can help tenants to raise their capacity utilization and the ir profit, next the platform that managed by the business unit can be broadened as further research. The platform designed to bring together customers and providers that supply customers' needs, such as a boarding house, laundry, document processing, transportation, hotel for parents, stationary, et cetera. This platform can give information to customers and also ease customers to get this service. For providers, this platform can provide an advantage because they can be recognized by customers broadly. After that, the customer and provider can create value co-creation; for example, the customer can provide feedback for service. Other further research also can be conducted by building value orchestration platform for other service sectors. 


\section{References}

Evanschitzky, H., Wangenheim, F. V and Woisetschlager, D. M. (2011), "Service \& Solution Innovation: Overview and Research Agenda", Industrial Marketing Management, 40(5), pp. 657660.

Grönroos, C. and Gummerus, J. (2014), "Managing Service Quality The Service Revolution and its Marketing Implications: Service Logic vs Service-Dominant Logic", Iss Journal of Service Management European Business Review Iss Journal of Service Management, 24(1), pp. 206-229.

Jiang, J. J., Kle in, G., Parolia, N. and Li, Y. (2012), "An Analysis Of Three SERVQUAL Variations In Measuring Information System Service Quality", The Electronic Journal Information Systems Evaluation, 15(2), pp. 149-162.

Kijima, K. and Arai, Y. (2016), "Value Co-Creation Process and Value Orchestration Platform", in Kwan, S. K., Spohrer, J. C., and Sawatani, Y. (eds) Global Perspectives on Service Science. Japan: Springer, pp. 137-154.

Korhonen, H. M. E. (2014), "Widening The Perspective On Industrial Innovation: A ServiceDominant-Logic Approach", Technology Innovation Management Review, May, pp. 31-39.

Ladhari, R. (2009), "A Review of Twenty Years Of SERVQUAL Research", International Journal of Quality and Service Sciences, 1(2), pp. 172-198.

Lusch, R. F. and Vargo, S. L. (2006), "Service-Dominant Logic: Reactions, Reflections and Refinements", Marketing Theory, 6(3), pp. 281-288.

Maglio, P. P., Vargo, S. L., Caswell, N. and Jim Spohrer (2009), "Service Science: Toward a Smarter Planet", in Karwowski and Salvendy (eds) Service Engineering. New York: Wiley, pp. 133.

Maglio, P. P., Vargo, S. L., Caswell, N. and Spohrer, J. (2009), "The Service System Is The Basic Abstraction of Service Science", Information Systems and e-Business Management, 7, pp. 395-406.

Mele, C., Colurcio, M. and Russo-Spena, T. (2014), "Research Traditions of Innovation: GoodsDominant Logic, The Resource-Based Approach, and Service-Dominant Logic", Managing Service Quality, 24(6), pp. 612-642.

Mont, O. K. (2002), "Clarifying The Concept of Product-Service System", Journal of Cleaner Production, 10(3), pp. 237-245.

Ng, I., Parry, G., Smith, L., Maull, R. and Briscoe, G. (2012), "Transitioning From a GoodsDominant To a Service-Dominant Logic: Visualising The Value Proposition Of Rolls-Royce", Journal of Service Management, 23(3), pp. 416-439.

Parasuraman, A., Zeithaml, V. A. and Berry, L. L. (1985), "A Conceptual Model of Service Quality and Its Implications for Future Research", Journal of Marketing, 49(4), pp. 41-50.

Quinn, R. E. and Cameron, K. (1993), "Organizational Life Cycles and Shifting Criteria Of Effectiveness: Some Preliminary Evidence", Management Science, 29(1), pp. 33-51.

Spohrer, J. C. and Maglio, P. P. (2010), "Toward a Science Of Service Systems Value and Symbols", in Handbook of service science. Boston, MA: Springer, pp. 157-194.

Spohrer, J. and Maglio, P. P. (2008), "The Emergence of Service Science: Toward Systematic Service Innovations to Accelerate Co-Creation of Value", Production and Operations Management, 
JOURNAL OF INTEGRATED S YSTEM VOL 2. NO. 2, DES EMB ER 2019: 112-122

17(3), pp. 238-246.

Vargo, S. L. and Lusch, R. F. (2004), "Evolving to a New Dominant Logic For Marketing", Journal of Marketing, 68, pp. 1-17.

Vargo, S. L. and Lusch, R. F. (2008), "Service-Dominant Logic: Continuing The Evolution", Journal of the Academy of Marketing Science, 36, pp. 1-10.

Wennerholm, E. (2012), "Transitioning From a Goods-Dominant to a Service-Dominant Logic: Visualizing The Role Of Remote Monitoring Systems". UMEA Universitet. 